\title{
NOTE
}

\section{Phytoplankton potential growth rate versus increase in cell numbers: estimation of cell lysis}

\author{
E. Garcés*, M. Masó \\ Institut de Ciències del Mar, P/Joan de Borbó, s/n, 08039 Barcelona, Spain
}

\begin{abstract}
The in situ growth rate of phytoplankton is defined as the potential growth rate without adjustment for losses due to cell mortality when it is measured by the cell cycle approach. In contrast, the method that assesses the cell number variation of the population in diffusion chambers takes cell mortality into account. We compare the 2 methods for natural blooms of dinoflagellates (Alexandrium minutum, Alexandrium taylori, Ceratium furca, Dinophysis sacculus, Gymnodinium pulchellum and Gyrodinium corsicum) grown in various situations and locations and data reported elsewhere. The in situ potential growth rates showed great intraspecific variability. The use of the differences between the 2 methods as a measure of in situ cell lysis is discussed.
\end{abstract}

KEY WORDS: Dinoflagellate $\cdot$ HABs $\cdot$ Growth rate $\cdot$ Loss rate Resale or republication not permitted without written consent of the publisher

Efforts in modeling harmful algal bloom (HAB) dynamics focus on the interactions between biological and physical processes. When testing a model against field data, the latter has many limitations, such as lack of spatial and temporal resolution and inappropriate criteria for the selection of the variables to measure (Franks 1997). Few studies report in situ specific growth rates during major events such as dinoflagellate proliferation (Chang \& Carpenter 1985, Reguera et al. 1996), since spatial and temporal monitoring of such events is extremely difficult. A lack of in situ growth and loss rates hinders modeling and thus the prediction of HABs.

Two methods are currently used to calculate growth rates: the cell cycle method (the mitotic index) (McDuff \& Chisholm 1982, Carpenter \& Chang 1988) and the cell number method, where the increase in cell number either in diffusion chambers (Furnas 1982) or in cultures is followed.

\footnotetext{
*E-mail: esther@icm.csic.es
}

The cell cycle method (the mitotic index) defines the phytoplankton growth rate as potential growth rate without adjustment for losses due to cell mortality (Chang \& Carpenter 1988, 1990), whereas the changes in cell numbers experienced by a population, either in diffusion chambers or in cultures, take into account losses of population as cell mortality. The 2 methodologies (potential growth rate and changes in cell numbers) have seldom been compared. Moreover, most data are from culture experiments (Olson \& Chisholm 1986, Chang \& Carpenter 1988, 1991, Antia et al. 1990, Pan \& Cembella 1998, Peperzak et al. 1998). The aim of the present paper is to review previous data and add new results from in situ measurements. We would like to point out that we contributed more than $80 \%$ of the data available from in situ studies.

Material and methods. To measure the in situ growth rate by cell cycle and changes in cell numbers (diffusion chamber method), experiments were carried out on several dinoflagellate proliferations, mainly in Alfacs Bay (Ebro Delta, NW Mediterranean Sea) and on the Catalan Coast (Table 1; Garcés et al. 1997, 1998, 1999, Garcés 1998).

The in situ potential growth rates were measured by taking phytoplankton samples of $2.5 \mathrm{l}$ every 2 to $3 \mathrm{~h}$ for $24 \mathrm{~h}$. Microfluorometry was then applied to measure the relative nucleic acid content of cells or to monitor the phase frequency of the cell cycle (as cytokinesis or recently divided cells as in the case of Dinophysis). The $\mathrm{S}$ and $\mathrm{G}_{2} \mathrm{M}$ phases were used as the terminal event with the equation:

$$
\mu=\frac{1}{n\left(T_{\mathrm{S}}+T_{\mathrm{G} 2 \mathrm{M}}\right)} \sum_{i=1}^{n}\left(t_{\mathrm{S}}\right) \ln \left[1+f_{\mathrm{S}}\left(t_{i}\right)+f_{\mathrm{G} 2 \mathrm{M}}\left(t_{i}\right)\right]
$$

where $\mu$ is an estimate of the in situ growth rate from DNA synthesis on Day $1, f_{\mathrm{S}}\left(t_{i}\right)$ and $f_{\mathrm{G} 2 \mathrm{M}}\left(t_{i}\right)$ are the fractions of cells in phases $\mathrm{S}$ and G2M at time $t_{i}$, respectively, $n$ is the number of samples collected during 1 
Table 1. Locations and times of the year for which the cell cycle method was applied to the different species in the Mediterranean area

\begin{tabular}{|c|c|c|c|c|c|c|}
\hline & Location & $\begin{array}{c}\text { Time of the } \\
\text { year }\end{array}$ & $\begin{array}{l}\text { Photoperiod } \\
\text { (h) }\end{array}$ & $\begin{array}{c}\text { Surface water } \\
\text { temperature }\left({ }^{\circ} \mathrm{C}\right)\end{array}$ & $\begin{array}{c}\mu \\
\left(d^{-1}\right)\end{array}$ & Source \\
\hline Alexandrium minutum & Arenys Harbour & Feb & $10: 14$ & 15 & $0.25-0.42$ & Garcés (1998) \\
\hline Alexandrium taylori & La Fosca & Aug & $14: 10$ & 27 & $0.4-0.5$ & Garcés et al. (1998) \\
\hline Dinophysis sacculus & Delta Ebro & $\begin{array}{l}\text { May-Jun } \\
\text { Oct }\end{array}$ & $\begin{array}{l}15: 9 \\
11: 13\end{array}$ & $\begin{array}{l}20 \\
17\end{array}$ & $\begin{array}{c}0.13-0.24 \\
0.11\end{array}$ & $\begin{array}{l}\text { Garcés et al. (1997) } \\
\text { Garcés et al. (1997) }\end{array}$ \\
\hline Ceratium furca & Delta Ebro & $\begin{array}{l}\text { Dec } \\
\text { Jan } \\
\text { Feb }\end{array}$ & $\begin{array}{r}9: 15 \\
10: 14 \\
10: 14\end{array}$ & $\begin{array}{r}12 \\
8 \\
13\end{array}$ & $\begin{array}{c}0.14 \\
0.13 \\
0.2-0.37\end{array}$ & $\begin{array}{l}\text { Garcés (1998) } \\
\text { Garcés (1998) } \\
\text { Garcés (1998) }\end{array}$ \\
\hline Gymnodinium pulchellum & Delta Ebro & Jan & $10: 14$ & 8 & 0.36 & Garcés (1998) \\
\hline Gyrodinium corsicum & Delta Ebro & $\begin{array}{l}\text { Dec } \\
\text { Jan } \\
\text { Feb }\end{array}$ & $\begin{array}{r}9: 15 \\
10: 14 \\
10: 14\end{array}$ & $\begin{array}{r}12 \\
8 \\
13\end{array}$ & $\begin{array}{c}0.94 \\
0.6 \\
0.39-0.59\end{array}$ & $\begin{array}{l}\text { Garcés et al. (1999) } \\
\text { Garcés et al. (1999) } \\
\text { Garcés et al. (1999) }\end{array}$ \\
\hline
\end{tabular}

daily cycle, $T_{\mathrm{S}}$ and $T_{\mathrm{G} 2 \mathrm{M}}$ are the durations of the $\mathrm{S}$ and G2M phases, respectively, $t_{\mathrm{S}}$ is the interval in hours and $t_{1}$ and $t_{2}$ correspond to the peak values in the number of cells in the $\mathrm{S}$ and G2M phases, respectively. The duration term $(T)$ was calculated by the following equation:

$$
\left(T_{\mathrm{S}}+T_{\mathrm{G} 2 \mathrm{M}}\right)=2\left(t_{2}-t_{1}\right)
$$

where $t_{1}$ and $t_{2}$ were determined from the time between the peaks of the S and G2M phases, estimated by fitting fourth-degree polynomial curves to the data (Carpenter \& Chang 1988, 1990).

To measure the changes in cell numbers (diffusion chamber method), water samples were incubated using $500 \mathrm{ml}$ diffusion cages with a permeable surface of $50 \mathrm{~cm}^{2}(10 \mu \mathrm{m}$ mesh). The samples were pre-filtrated with a $150 \mu \mathrm{m}$ mesh to exclude grazers. The chambers were incubated at $0.5 \mathrm{~m}$ depth, and dinoflagellates were exposed to natural irradiance, temperature and photoperiod for $24 \mathrm{~h}$. Initial and final samples were removed from the cages. Accurate counts of the incubation samples were performed and changes in cell number were measured (Guillard 1973):

$$
\mu=\frac{1}{\left(t_{2}-t_{1}\right)} \ln \frac{N_{2}}{N_{1}}
$$

where $\mu$ is the net growth rate in $\mathrm{d}^{-1}$ and $N_{2}$ and $N_{1}$ are the cell concentration at $t_{2}$ and $t_{1}$ respectively.

Results and discussion. Our results show that the intraspecific spatial-temporal variability of in situ potential growth rates was highly significant (Table 1); for example, the potential growth rate of Gyrodinium corsicum ranged from 0.3 to $0.9 \mathrm{~d}^{-1}$. Moreover, the growth rates measured at different locations at the same time varied by a factor of 1.5 , showing that the growth rate reflected the response of organisms to the environment (Garcés et al. 1999). In the same in situ conditions, the potential growth rate of a co-occurring dinoflagellate, Ceratium furca, was between 0.1 and $0.37 \mathrm{~d}^{-1}$.

Some dinoflagellates do not grow well in enclosures, which leads to an underestimation of the growth rate calculated from changes in cell number. It is out of the scope of the present paper to discuss these limitations - that has been done before (Chang \& Carpenter 1988, 1990, 1991) - but some specifications are necessary. The natural population may divide actively, but the enclosure is not a suitable environment for measuring growth rate. For example, incubations of high cell densities (as in the case of huge dinoflagellate proliferations) directly influence growth conditions and can produce an effect of no growth (Agustí \& Kalff 1989), while the natural population would be dividing actively. This is what happens with G. corsicum, which produces a high amount of mucus. Thus, the growth rate measured in incubation cages is not appropriate in these cases, and so it will not be considered in the following discussion.

The relationship between potential growth rate by cell cycle and growth rate by cell increase, in either cultures or diffusion chambers, is shown in Fig. 1, where the 2 lines show no losses (1:1) and maximum loss rate found $\left(0.4 \mathrm{~d}^{-1}\right)$. The concept of phytoplankton death or mortality is understood to encompass all phytoplankton losses, which includes all the processes that remove phytoplankton cells from the system (grazing, cell lysis, dispersion, sinking). We can assume that the difference (loss rate) between potential growth and cell increase is only due to physiological death and subsequent cell lysis, since other sources of loss (like grazing) have been avoided. In addition, it can be considered that loss due to sinking is negligible, because we are dealing with dinoflagellates.

Cell lysis may result from various factors in natural populations, including attack by parasites (Noren et al. 


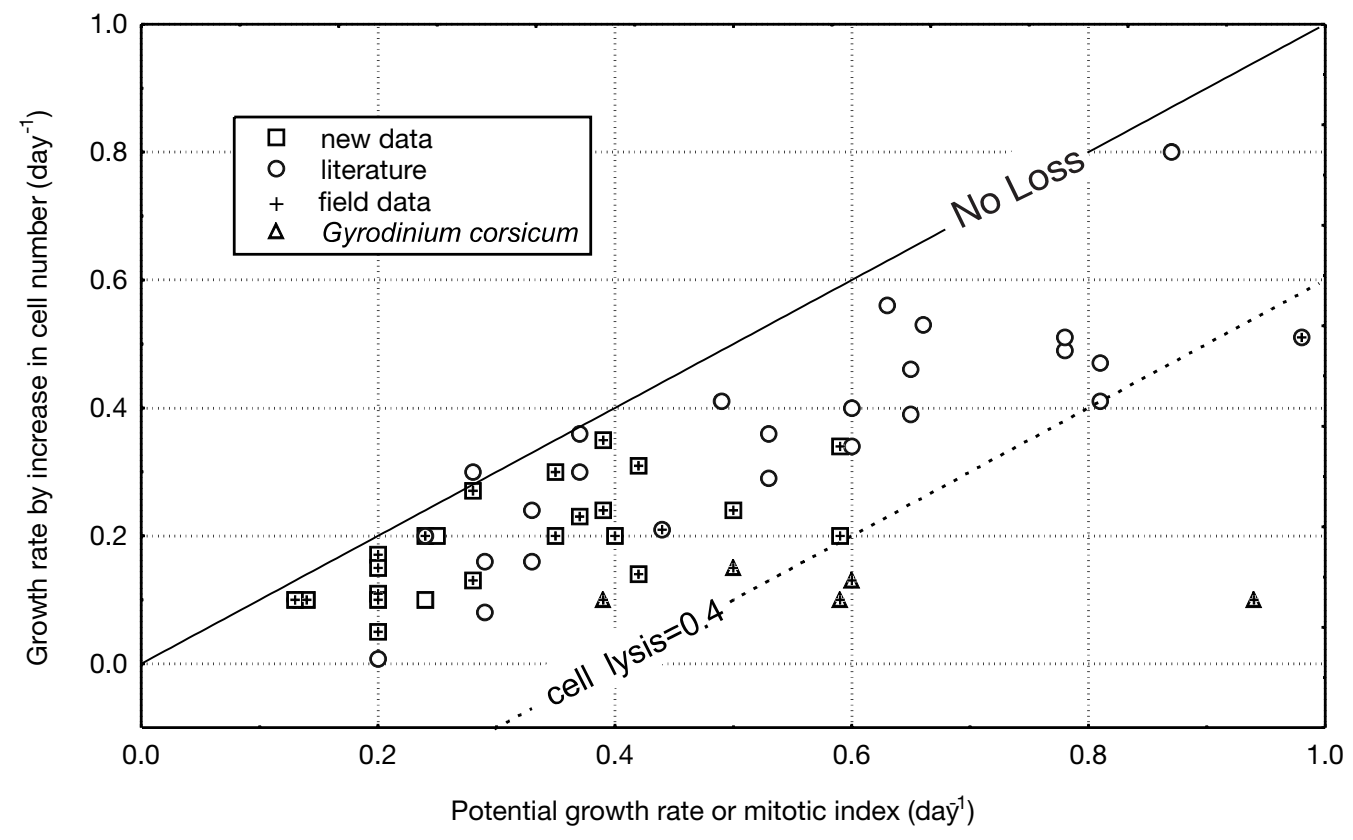

Fig. 1. Association between potential growth rate by cell cycle (mitotic index) and growth rate by increase in cell number. Lines have been added to show the bounds of no losses and cell lysis of $0.4 \mathrm{~d}^{-1}$

1999, Erard Le Denn et al. 2000), viruses (Suttle 1994), bacteria (Doucette 1995) and fungi. Phytoplankton cell lysis results in the release of the cell contents and therefore in an increase in nutrient-rich dissolved organic components. Furthermore, cell lysis appeared to be the third major loss factor determining algal bloom dynamics (Brussaard et al. 1995). Despite the potential importance of cell lysis, field studies on cell lysis rates are scarce (van Boekel et al. 1992, Agustí et al. 1998). Agustí et al. (1992) found ranges from 0.026 to $1.9 \mathrm{~d}^{-1}$ in the Mediterranean phytoplankton community; cell lysis rates were higher in surface waters, where gross growth rates were also higher and biomass lower than in the deep chlorophyll maximum that characterize the area.

Not only are there very few field studies on cell lysis rates, but very little is known about in situ growth and loss rates of phytoplankton at the species level (e.g., Furnas 1990). The problems in quantifying speciesspecific growth and loss rates in a natural plankton assemblage are in part due to the multitude of processes involved. Various techniques have been used to measure phytoplankton cell lysis (dissolved esterase activity assay, direct cell counts and viability assays), but at present there is still a lack of reliable methods to quantify the process. One of the major problems is confusion about the definition of cell death. For instance the significance of internally driven mortality (apoptosis) is still unclear. An approach that can provide the complete set of growth and loss parameters for a par- ticular phytoplankton species is to combine the cellcycle analysis (potential growth rate) (Carpenter \& Chang 1988) in field with the actual changes in cell numbers.

Our compilation of the 2 methods to measure growth rate, both in culture and in the field, suggest a wide range ( 0.01 to $0.4 \mathrm{~d}^{-1}$ ) of cell lysis rates (Fig. 1$)$. The fact that differences between growth rates are significant and can reach $50 \%$ indicated that this loss rate is significant in nature. Concurrent measurements of growth rates and realised increases in cell numbers may provide useful constraints for HAB models.

Acknowledgements. This study was supported by CIRIT grant F1/94 8003 and field work was partially supported by the Agencia Catalana de l'Aigua, Generalitat de Catalunya. The authors wish to thank the anonymous reviewers whose valuable criticisms substantially improved the manuscript.

\section{LITERATURE CITED}

Agustí S, Kalff J (1989) The influence of growth conditions on the size dependence of maximal algal density and biomass. Limnol Oceanogr 34:1104-1108

Agustí S, Satta MP, Mura MP, Benavent E (1998) Dissolved esterase activity as a tracer of phytoplankton lysis: evidence of high phytoplankton lysis rates in the northwestern Mediterranean. Limnol Oceanogr 43:1836-1849

Antia AN, Carpenter EJ, Chang J (1990) Species specific phytoplankton growth rates via diel DNA synthesis cycles. III. Accuracy of growth rate measurement in the dinofla- 
gellate Prorocentrum minimum. Mar Ecol Prog Ser 63: 273-279

Brussaard CPD, Riegman R, Noordeloos AAM, Cadée GC, Whitte H, Kop AJ, Nieuwland G, van Duyl FC, Bak RPM (1995) Effects of grazing, sedimentation and phytoplankton cell lysis on the structure of a coastal pelagic food web. Mar Ecol Prog Ser 93:39-48

Carpenter EJ, Chang J (1988) Species specific phytoplankton growth rates via diel DNA synthesis cycles. I. Concept of the method. Mar Ecol Prog Ser 43:105-111

Chang J, Carpenter EJ (1985) Blooms of the dinoflagellate Gyrodinium aureolum in a Long Island estuary: box model analysis of bloom maintenance. Mar Biol 89:83-93

Chang J, Carpenter E (1988) Species specific phytoplankton growth rates via diel DNA synthesis cycles. II. DNA quantification and model verification in the dinoflagellate Heterocapsa triquetra. Mar Ecol Prog Ser 44:287-296

Chang, J, Carpenter EJ (1990) Species specific phytoplankton growth rates via diel DNA synthesis cycles. IV. Evaluation of the magnitude of error with computer simulated cell populations. Mar Ecol Prog Ser 65:293-304

Chang J, Carpenter EJ (1991) Species specific phytoplankton growth rates via diel DNA synthesis cycles. V. Application to natural populations in Long Island Sound. Mar Ecol Prog Ser 78:115-122

Doucette GJ (1995) Interactions between bacteria and harmful algae: a review. Natural Toxins 3:65-74

Erard Le Denn E, Chretiennot Dinet MJ, Probert I (2000) First report of parasitism on the toxic dinoflagellate Alexandrium minutum Halim. Estuar Coast Shelf Sci 50:109-113

Franks P (1997) Models of harmful algal blooms. Limnol Oceanogr 42:1273-1282

Furnas MJ (1982) An evaluation of two diffusion culture techniques for estimating phytoplankton growth rates in situ. Mar Biol 70:63-72

Furnas MJ (1990) In situ growth rates of marine phytoplankton: approaches to measurement, community and species growth rates. J Plankton Res 12:1117-1151

Garcés E (1998) Proliferacions de dinoflagellades a la Costa Catalana: estudi del creixement in situ i adaptacions per al manteniment. $\mathrm{PhD}$ thesis, Universitat de Barcelona

Garcés E, Delgado M, Camp J (1997) Phased cell division in natural population of Dinophysis sacculus and the in situ measurement of potential growth rate. J Plankton Res 19: 2067-2077

Garcés E, Delgado M, Maso M, Camp J (1998) Life history

Editorial responsibility: Otto Kinne (Editor),

Oldendorf/Luhe, Germany and in situ growth rates of Alexandrium taylori (Dinophyceae, Pyrrophyta). J Phycol 34:880-887

Garcés E, Delgado M, Maso M, Camp J (1999) In situ growth rate and distribution of the ichthyotoxic dinoflagellate Gyrodinium corsicum Paulmier in an estuarine embayment (Alfacs Bay, NW Mediterranean Sea). J Plankton Res 21:1977-1991

Guillard RRL (1973) Methods for microflagellates and nannoplankton. In: Stein JR (ed) Handbook of phycological methods. Culture methods and growth measurements. Cambridge University Press, Cambridge, p 69-85

McDuff RE, Chisholm SW (1982) The calculation of in situ growth rates of phytoplankton populations from fractions of cells undergoing mitosis: a clarification. Limnol Oceanogr 27:783-788

Noren F, Moestrup O, RehnstamHolm AS (1999) Parvilucifera infectans Noren et Moestrup gen. et sp nov (Perkinsozoa phylum nov.): a parasitic flagellate capable of killing toxic microalgae. Eur J Protistol 35:233-254

Olson RJ, Chisholm SW (1986) Effects of light and nitrogen limitation on the cell cycle of the dinoflagellate Amphidinium carteri. J Plankton Res 8:785-793

Pan Y, Cembella D (1998) Flow cytometric determinations of cell cycle and growth rates of Prorocentrum spp. In: Reguera B, Blanco J, Fernandez ML, Wyatt T (eds) VIII International Conference on Harmful Algae. Xunta de Galicia, Vigo, and Intergovernmental Oceanographic Commission of UNESCO, p 173-174

Peperzak L, Sandee B, Jonker R, Legrand C (1998) Measurement of Prorocentrum micans growth rate by flow cytometric analisys of the diel DNA cycle. In: Reguera B, Blanco J, Fernandez ML, Wyatt T (eds) VIII International Conference on Harmful Algae. Xunta de Galicia, Vigo, and Intergovernmental Oceanographic Commission of UNESCO, Vigo, p 177-178

Reguera B, Bravo I, McCall H, Reyero MI (1996) Phased cell division and other biological observations in field populations of Dinophysis spp. during cell cycle studies. In: Yasumoto T, Oshima Y, Fukuyo Y (eds) Harmful and toxic algal blooms. IOC (UNESCO), Paris, p 257-260

Suttle CA (1994) The significance of viruses to mortality in aquatic microbial communities. Microb Ecol 28:237-243

van Boekel WHM, Hanse FC, Riegman R, Bak RPM (1992) Lysis-induced decline of a Phaeocystis spring bloom and coupling with the microbial food web. Mar Ecol Prog Ser 81:269-276

Submitted: April 25, 2000; Accepted: December 15, 2000

Proofs received from author(s): February 28, 2001 